determination in turtles: ecological and behavioral aspects. Herpetologica 38:156-164.

WATERS, J.C. 1974. The biological significance of the basking habit in the black-knobbed sawback, Graptemys nigrinoda Cagle. MSc Thesis, Auburn University, Auburn, Alabama.

Webi, R.G. 1961. Observations on the life histories of turtles (Genus Pseudemys and Graptemys) in lake Texoma, Oklahoma. American Midland Naturalist 65:193-214.

Received: 10 July 2007

Revised and Accepted: 23 September 2008

Chelonian Conservation and Biology, 2008, 7(2): 281-285 (c) 2008 Chelonian Research Foundation

\section{Cultural Exploitation of Freshwater Turtles in Sarawak, Malaysian Borneo}

\author{
Karen A. Jensen ${ }^{1,2}$ AND IndRaneil Das ${ }^{1}$ \\ ${ }^{1}$ Institute of Biodiversity and Environmental Conservation, \\ Universiti Malaysia Sarawak, 94300, Kota Samarahan, \\ Sarawak, Malaysia [hamadryad2004@hotmail.com]; \\ ${ }^{2}$ Present Address: 473 South River Road, Suite 1-255, St George, \\ Utah 84790 USA [kitti_jensen@yahoo.com]
}

Abstract. - We investigated the cultural exploitation of nonmarine turtles in Sarawak State, Malaysia. Turtles are primarily used for food, and the Asian softshell turtle, Amyda cartilaginea, appears to be the most desirable species. Other local demands include the pet trade, which involves both local and exotic species of turtles.

Bushmeat, the flesh of wild animals, is an important source of protein for many people (Chardonnet et al. 2002) and takes on an unusual importance in the diet and cultures of many indigenous peoples of the tropics. Although hunting itself has some support (e.g., Feer 1994), there is much opposition to the activity (Robinson and Bennett 2000), based on either ethical or conservation grounds. Legislation in many parts of the world, nonetheless, permits harvest, largely with the goal of achieving sustainability and also for public support of conservation (Keylock 2002).

Hunting of wild turtles for food has been a long-term human occupation, as indicated from studies of kitchen middens and archaeological sites from all continents (Adler 1970; Rhodin 1995; Rybczynski et al. 1996; Earl of Cranbrook 2000; Erlandson 2001; Širokỳ et al. 2004), and one presumed effect is reduction of body size, as reported from comparison of recent populations with conspecifics in the fossil record (e.g., Lydekker 1889; Bour 1980). Although a number of reported extinctions from the Plio-Pleistocene records have been proved false (e.g., Das 1991, 1994), recovery of undescribed turtle species has been reported from human material remains in some localities, such as one in Zaire (Meylan 1990). In a contemporary context, human utilization of turtles is both widespread and locally intensive where populations permit their use, leading to serious conservation problems (Thorbjarnarson et al. 2000).

Most of the attention to the global turtle crisis has been directed to China, the primary consumer of turtles in recent years, rather than to most other adjacent or regional Asian countries, which are the sources or potential sources of turtles in the trade. One such area is Borneo, the world's third largest island, located in the Malay Archipelago and considered a center of global biodiversity. The island is under the jurisdiction of three countries: Indonesia, Malaysia, and Brunei Darussalam. Sarawak is one of the 2 Malaysian states located on the island (Fig. 1), the other being Sabah. The dominant ethnic group of Sarawak is Iban; other important indigenous groups include the Bidayuh, Kelabit, Lun Bawang, Melenau, Kenyah, Kayan, and other more marginalized nomadic groups, such as the Penans. In urban centers and coastal regions, more recent immigrants include the Chinese and Malay.

Perceptions of wildlife and their use as food may vary with the group concerned. For instance, Malays (and many Melanaus) are followers of Islam, which prohibits the consumption of turtle flesh (considering it "haram," or unlawful food), on account of the amphibious nature of a majority of these species. Nonetheless, eggs may be consumed by some. For a majority of the indigenous groups in Borneo, turtle is a source of occasional protein, harvested incidentally when hunting in the forest for bearded pigs or other larger game or caught deliberately by fishermen using baited line or by finding them in the mud in shallow sections of rivers. For the generally more affluent Chinese, turtles represent both an expensive delicacy, served in seafood restaurants, and a source of medicine for treatment of a variety of ailments (Read 1937).

The most recent island-specific identification guide to the turtle fauna of Borneo is that of Lim and Das (1999). Native nonmarine turtle species previously noted from Sarawak include 2 softshell species (Family Trionychidae), the Asian softshell turtle (Amyda cartilaginea) and the Malayan softshell turtle (Dogania subplana). Hardshell turtles known from Sarawak include 7 species from the family Geoemydidae: the painted terrapin (Batagur borneoensis), the Malayan box turtle (Cuora amboinensis), the Asian leaf turtle (Cyclemys dentata), the spiny hill turtle (Heosemys spinosa), the Malayan flat-shelled turtle (Notochelys platynota), the Asian giant turtle (Orlitia borneensis), and the black pond turtle (Siebenrockiella crassicollis); and 1 species from the family Testudinidae, the Asian brown tortoise (Manouria emys). Two nonnative turtle species are known to be established in some parts of Sarawak (Lim and Das 1999; Jensen and Das 2006): these 